\title{
Identification of the Grindulu Fault in Pacitan, East Java using Magnetic Method
}

\section{Latifatul Cholifah ${ }^{1, a, *}$, Nurul Mufidah ${ }^{2, b}$, Eden Lazuardi ${ }^{2, \mathrm{c}}$, Bagus Jaya Santosa ${ }^{2, \mathrm{~d}}$, Sungkono ${ }^{2, \mathrm{e}}$, and Arif Haryono ${ }^{3, \mathrm{f}}$}

${ }^{1}$ Physics Department, Graduate Program, Institut Teknologi Sepuluh Nopember Kampus ITS Keputih, Sukolilo, Surabaya 60111, Indonesia

${ }^{2}$ Physics Department, Institut Teknologi Sepuluh Nopember

Kampus ITS Keputih, Sukolilo, Surabaya 60111, Indonesia

${ }^{3}$ Physics Department, Doctoral Program, Institut Teknologi Sepuluh Nopember

Kampus ITS Keputih, Sukolilo, Surabaya 60111, Indonesia

e-mail: ${ }^{\mathrm{a}}$ latifah.cholifah@gmail.com, ${ }^{\mathrm{b}}$ nurulmufidah231298@gmail.com, ${ }^{\mathrm{c}}$ edenlazuardi@gmail.com,

${ }^{\mathrm{d}}$ bjs@physics.its.ac.id, ${ }^{\mathrm{e}}$ hening27@gmail.com, and ${ }^{\mathrm{f}}$ gamapad@gmail.com

* Corresponding Author

\begin{abstract}
Magnetic method in geophysical surveys is common for its non-destructive use of sub-surface structure delineation. In this study, ground-based measurements of magnetic intensity were performed using a set of instruments in some regions of Pacitan, a city in the southern area of East Java province. Based on these measurements, data acquisition was used to identify the Grindulu faulting zone in the region of interest, potentially vulnerable to geohazards. The data were first corrected using the IGRF and diurnal corrections. A filtering technique of upward continuation at a height of $900 \mathrm{~m}$ was then applied to separate local anomalies from regional ones as the targeted sources in the present case. These separate anomalies and their corresponding reductions to the poles as further filtering processes were analyzed for predicting the location and direction of the fault. The results, extracted from data analysis and interpretation, show that the main path of the Grindulu is directed along the NE-SW fault line or $N 60^{\circ} E$. The resulting anomalies also reflect that the Grindulu is a normal fault with surrounding minor faults lying across the Grindulu, calling for increased awareness of vulnerability in the city to seismic threats.
\end{abstract} Keywords: Grindulu Fault; Pacitan; magnetic method

\section{Identifikasi Sesar Grindulu di Pacitan, Jawa Timur menggunakan Metode Magnetik}

\begin{abstract}
Abstrak
Metode magnetik telah biasa digunakan dalam survei geofisika untuk menggambarkan struktur fisis bawah permukaan. Dalam penelitian ini, pengukuran magnetik dengan memanfaatkan seperangkat instrumen magnetik dilaksanakan di beberapa wilayah Pacitan, Provinsi Jawa Timur bagian selatan. Berdasarkan hasil survei magnetik, akuisisi data magnetik dilakukan dan kemudian digunakan untuk mengidentifikasi sesar Grindulu di lokasi penelitian yang tergolong rentan terhadap bencana geologi. Data magnetik dikoreksi terlebih dahulu dengan menggunakan model IGRF dan variasi harian diurnal. Teknik pemfilteran kontinuasi ke atas sampai pada ketinggian $900 \mathrm{~m}$ kemudian diterapkan untuk
\end{abstract}

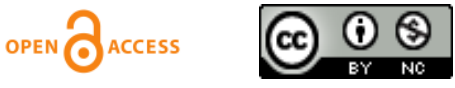


pemisahan anomali lokal dari anomali regional sebagai sumber target. Kedua jenis anomali tersebut selanjutnya diproses dengan filter reduksi ke kutub untuk memprediksi lokasi dan arah sesar Grindulu. Analisis hasil transformasi reduksi ke kutub dan interpretasi data menunjukkan bahwa jalur utama sesar Grindulu berada sepanjang arah timur laut-barat daya atau arah $N 60^{\circ}$ E. Kedua kontur anomali hasil transformasi reduksi ke kutub juga menunjukkan bahwa sesar Grindulu merupakan sesar normal dikelilingi oleh sesar lokal yang memotong jalur sesar Grindulu. Temuan penelitian ini meningkatkan kesadaran terhadap kerentanan wilayah dan potensi ancaman bencana seismik di Kabupaten Pacitan.

Kata Kunci: Sesar Grindulu; Pacitan; metode magnetik

PACS: 91.30.Dk; 91.30.Iv; 91.30.pd; 91.45.Vz; 93.85.Jk

(C) 2020 Jurnal Penelitian Fisika dan Aplikasinya (JPFA). This work is licensed under CC BY-NC 4.0

\begin{tabular}{|c|c|c|c|c|c|c|}
\hline Article History: Received: May 22, 2020 & \multicolumn{6}{|c|}{ Approved with minor revision: June 8, 2020} \\
\hline Accepted: July 13,2020 & & Published: Jur & 0,2020 & & & \\
\hline How to cite: Cholifah L, et al. Identificatic & of the Grind & dulu Fault in & $\tan , \mathrm{Ea}$ & ava usin & Magne & thod. \\
\hline $\begin{array}{l}\text { Jurnal Penelitian Fisika dan } \\
\text { https://doi.org/10.26740/jpfa.v10n1.p-22-33 }\end{array}$ & Aplikasinya & (JPFA). & 2020; & 10(1): & 22-33. & DOI: \\
\hline
\end{tabular}

\section{INTRODUCTION}

The magnetic method is commonly used in geophysical surveys with its non-destructive techniques for ease of sub-surface structure delineation. This advantage is stated either in a literature, for example, or in research papers [1-3]. This method relies upon field measurements of magnetic intensity using various techniques for specific purposes, including identification of a fault zone, as in [4-6]. This is of significance as seismicity in an active fault can be a potential source of earthquakes of tectonic origin, as is the case in West Java [7].

In the context of Indonesia, particularly in the eastern part of the Sunda-Banda arc active fault mapping may help to reduce risks and fatalities in society living in vulnerable regions to geological hazards [8,9], as well as other earth-related hazards imposed by lithospheric collision beneath the surface [10]. These studies, however, have not examined the southern part of East Java, for example Pacitan, which is considered prone to seismic threats by $[11,12]$ using geophysical methods other than magnetic survey. Located in the extent of the Southern Mountains arc in Java $[13,14]$, Pacitan is fragile to earthquakes.
Despite its high seismicity, hazard analysis focusing on vulnerability in Pacitan is rare to conduct.

In the present work, we address this issue by performing magnetic survey during field work in Pacitan, a city in the region of interest, to delineate the Grindulu faulting zone, believed to be the possible major cause for earthquake-related disasters in the city in the future. The objective of this work is thus to identify and locate the fault in quest as part of disaster risk reduction to a minimum level for local community.

In measurements of magnetic intensity, potential field and corresponding magnetic anomalies are possibly correlated to the level of crustal seismicity [15]. A further technique using a combined method of magnetic and gravity surveys can also effectively be used to map sources of seism-tectonic activities beneath the surface [16]. This study, however, focuses only on magnetic method to examine the location and direction of the Grindulu.

In many practices, the total field intensity measured is unfortunately unavoidable mixed with undesirable sources of magnetic field. Among these are the geodynamic processes at the Earth's outer 
core $[17,18]$ and external influences from lunar and solar activities [19]. Due to these noises, [20] suggested that field magnetic data acquired are initially evaluated by subtracting them from the main field and diurnal variation at the time of measurements. Data corrections, data processing and further analysis for data refinement are provided in the following methodology.

\section{METHOD}

The field data used in this study were obtained from magnetic surveillance in some municipals of Pacitan, covering regions of Gunungsari and Arjosari, and in town during 23-30 October 2019. The city of Pacitan is geographically situated between $7.9^{\circ}-8.3^{\circ} \mathrm{S}$ and $110.9^{\circ}-111.4^{\circ} \mathrm{E}$ in the southern East Java. Shown in Figure 1 is study area coverage, with geological settings in the study area are dominated by sedimentary, volcanic and intrusive rocks [21,22].
A set of sensitive field equipment used in the measurements of magnetic intensity included two magnetometers with precision of $0.1 \mathrm{nT}$, Global Positioning System (GPS), and a geological compass. Among the two, the first magnetometer, Proton Precession Magnetometer (PPM) Envi Scientrex, was placed at the base station to record temporal variation of the total field intensity where the base-station readings were taken every 5 minutes.

The second magnetometer, Geoproton magnetometer, was then used as a mobile instrument to acquire magnetic intensity in each point of measurement along with 3 lines of measurements across the possible location of the Grindulu with separate adjacent points of $200 \mathrm{~m}$ and line spacing was set to $5 \mathrm{~km}$. Both the GPS and the compass were utilized to locate accurately all points of measurement. A total of 104 dataset-points were finally acquired in the field measurements for data acquisition and processing.

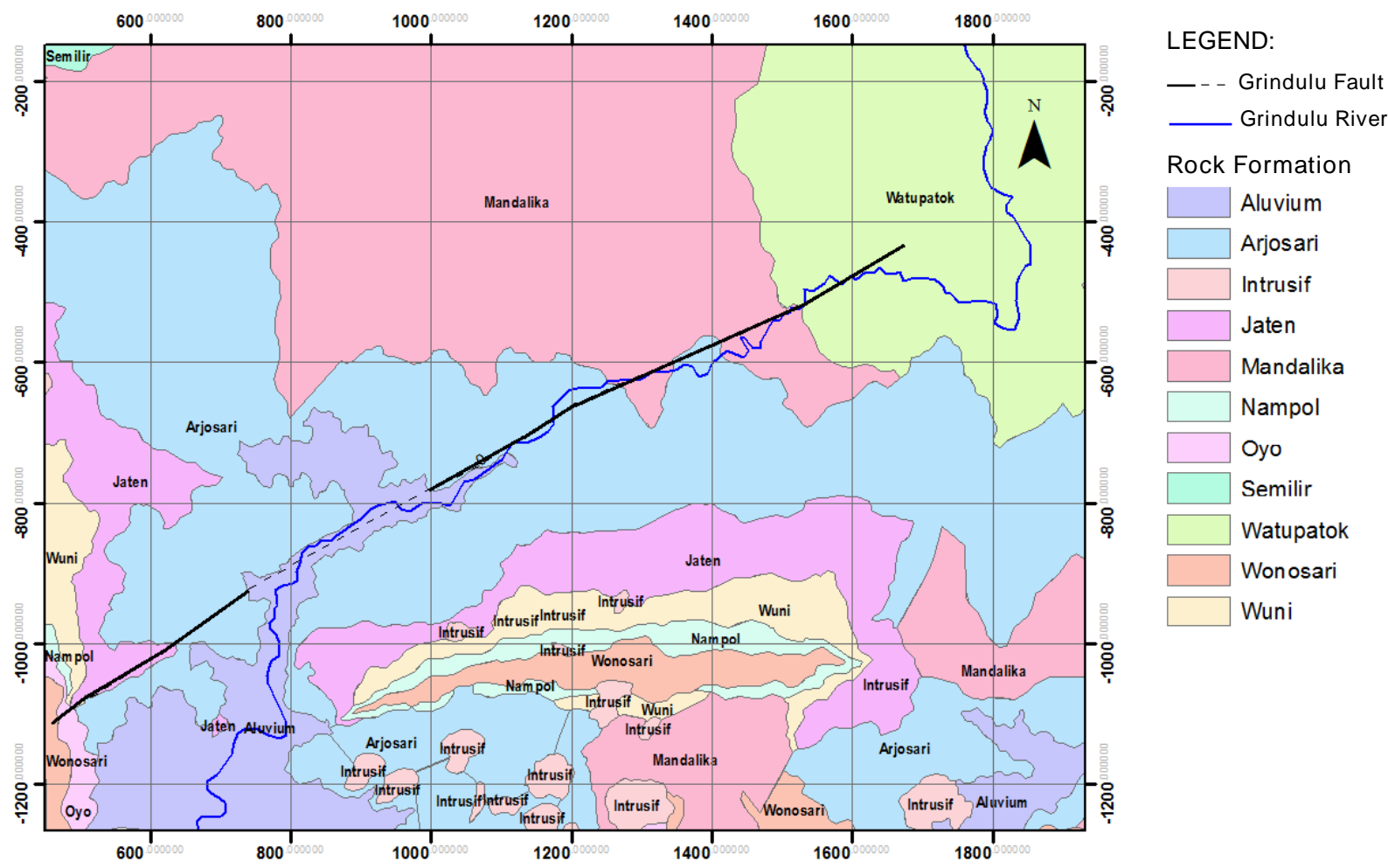

Figure 1. Geological Map Overlying on Geographical Location for Magnetic Surveillance in this Study (Made Available Using ArcGIS Online Basemaps Freely Accessible at https://arcgis.com/home/group.html) 
The data from the field survey were first corrected using calculated intensities of the main field given by the 12th Generation of International Geomagnetic Reference Field (IGRF) model [23,24]. The calculations were made possible online by the World Data Centre (WDC) for global magnetic data here named as $B_{\mathrm{IGRF}}$ and freely accessible at http://wdc.kugi.kyoto-u.ac.jp/igrf/point/index .html.

Diurnal correction was then performed to account for daily effects of solar activities. This correction is symbolized as $B_{\mathrm{VH}}$ and here estimated to be

$$
B_{\mathrm{VH}}=B_{\text {base }}(t)-B_{\text {base }}(t-1)
$$

with $B_{\text {base }}(t)$ denotes the base-station reading on a particular day and $B_{\text {base }}(t-1)$ is the reading on a day before. With the total field intensity $B$ measured by the portable instrument, magnetic anomaly acquired from the survey $\Delta B$ is written as follows,

$$
\Delta B=B-B_{\mathrm{IGRF}}-B_{\mathrm{VH}}
$$

The resulting anomaly derived from Equation 2 was plotted using Surfer 11 to obtain magnetic anomaly contours. However, these contours remained containing mixed magnetic anomalies between local and regional anomalies. Using Magpick, upward continuation was applied to accentuate the effect of regional anomaly from deep sources at the expense of local anomaly from shallow sources [25].

The resulting separation of magnetic anomalies were both processed by reduction to the pole (RTP) transformation using the same application to remove the skewness of the anomalies due to arbitrary magnetization of the sources, making them to be vertically magnetized [26]. The final anomaly contours were analyzed to predict the possible position and direction of the Grindulu.

\section{RESULTS AND DISCUSSION}

The fact that the total field intensities $B$ observed from magnetic measurements are indistinguishable from those imposed by the effects of the Earth's main magnetic field and the secondary sources is an inherent problem in the measurements [20]. This allows us to have these intensities left uncorrected. Plot of uncorrected values of the $B$ field intensity is provided in Figure 2, where the observed intensities ranging from 43,750 to $45,250 \mathrm{nT}$ (the global geomagnetic field varies between $30,000 \mathrm{nT}$ in the equator and 65,000 $\mathrm{nT}$ at the two poles for comparison).

The $B$ field observed for all points of measurements was then evaluated by taking the IGRF model [24] and diurnal corrections [19] into account for first order corrections.

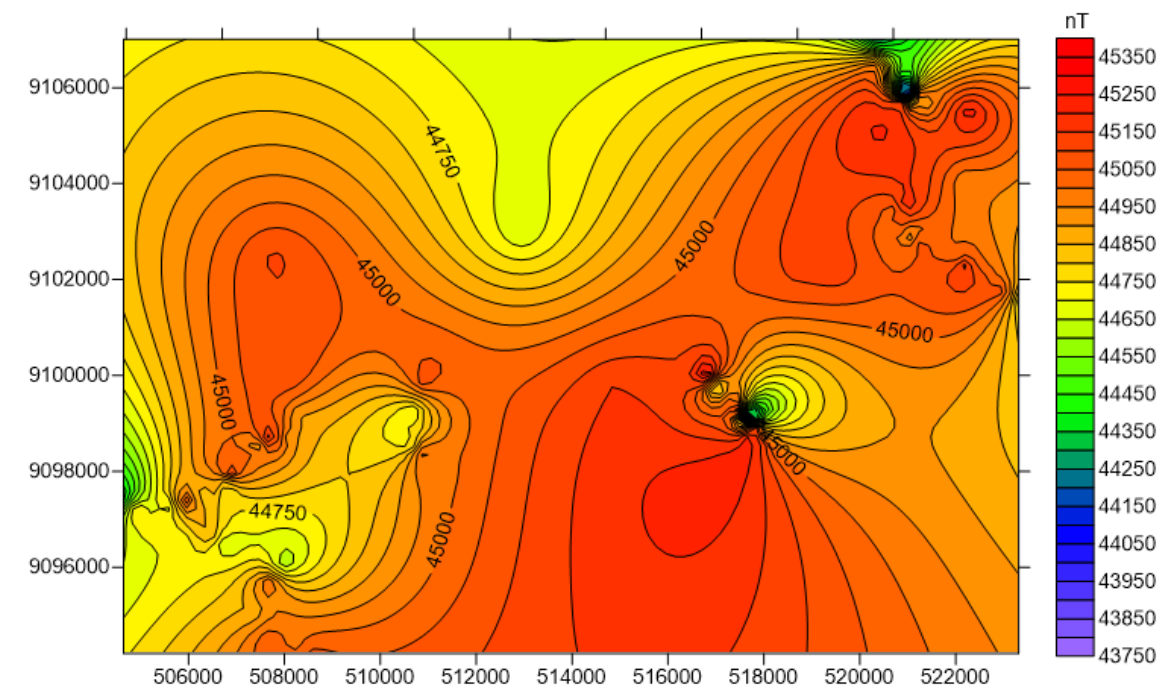

Figure 2. Contour for the Total Field Intensity Observed in the Study Area by Portable Instrument 
As part of these first order corrections, the IGRF model is in fact not the only model for the global magnetic model. There are 6 global magnetic models, including the IGRF that provide similar values of intensities for higher degrees of spherical harmonics terms of up to degree 13, with negligible difference in the measured intensities among the models of a relatively small value of only $1 \mathrm{nT}$ [27]. It follows that any model could be possibly used for the main field correction. The IGRF is here selected as a matter of preference for its relatively ease of online accessibility [24].

The effects of diurnal corrections are attributable to relatively small contributions in magnitude to the main field with temporal variations of shorter than a day, the so-called daily variations, which are mainly induced by atmospheric disturbances [28]. Note here that spatial variations of the main field arguably generated by permanently magnetized buried bodies underneath and near the surface [29], as is the case in the present work, have been incorporated into the $B$ field measurements (but are classified into unexpected sources).

It should be noted here that the above first order corrections are, in field practice of magnetic measurements, normally completed with the second order correction. This type of correction is mainly owing to the presence of magnetic storm in field locations at the times of the measurements as additional noises that may interfere the observed intensities [30].

Regarding the second order correction, we examined if the surveys during a period of 23-30 October 2019 were well performed in 'quiet days' of no disturbance. In response to these possible errors, we confirm to use the so-called Dst index, freely accessed at http://wdc.kugi.kyoto-u.ac.jp/dst_realtime/20 1910/index.html for a reliable indicator here, as depicted in Figure 3.

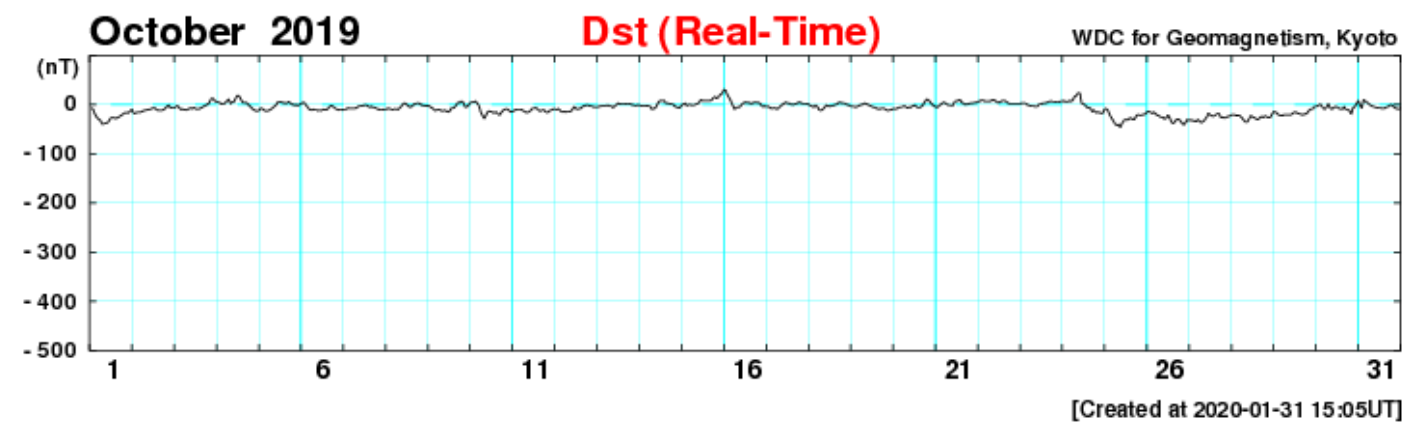

Figure 3. Dst Index During October 2019 (Taken from http://wdc.kugi.kyoto-u.ac.jp/dst_realtime/)

Based on Figure 3, magnetic disturbance during field magnetic surveys were observed in the range of 0 down to $-46 \mathrm{nT}$. This is classified into 'weak storm' [30] for which all the measured magnetic intensities are then acceptable with no further revisions.

Magnetic anomaly $\Delta B$ was calculated using the total $B$ field reduced by the IGRF and the diurnal corrections, as indicated by Equation 2. The resulting magnetic anomaly is illustrated in Figure 4 with minimum and maximum values are, respectively, found to be $-2400 \mathrm{nT}$ and $1400 \mathrm{nT}$. The observed negative and positive anomalies represent the presence of magnetic dipoles distributed over the surveyed area. These pairs of anomalies go with dominant features of small and large closures, indicating shallow sources of short wavelengths or high frequencies (referred to here as local anomalies) and deeper sources of longer wavelengths or lower frequencies (considered here to be regional anomalies), respectively $[1,11,16]$.

Final data reduction in intensity comes from a local terrain or topographic correction in particular when measurements are carried out from one irregular surface to another [1]. The most common technique in this matter is to reduce field data to a horizontal plane of the same height measured from the reference 
although some uncertainties in estimates of magnetic distortion are left uncorrected.

Following methodology given in [31], we estimate the maximum distortion of intensity to be approximately $57 \mathrm{nT}$, proportional to deviation in the measurements of up to $1 \%$ (relative to the mean intensity averaged over space and time for the total field of about 45,000 nT). This relatively small deviation in intensity measured during field observations indicates that data reduction using this filter is not necessary.

Back to Figure 4, both the anomalies contained in the contour, however, have not clearly identified the location of the Grindulu fault zone. For this reason, a next stage using a filtering geophysical technique of upward continuation $[1,25]$ was therefore carried out to separate the mixed anomalies originating from different relative depths of sources [16]. This stage eventually results in two separate contours of anomalies.

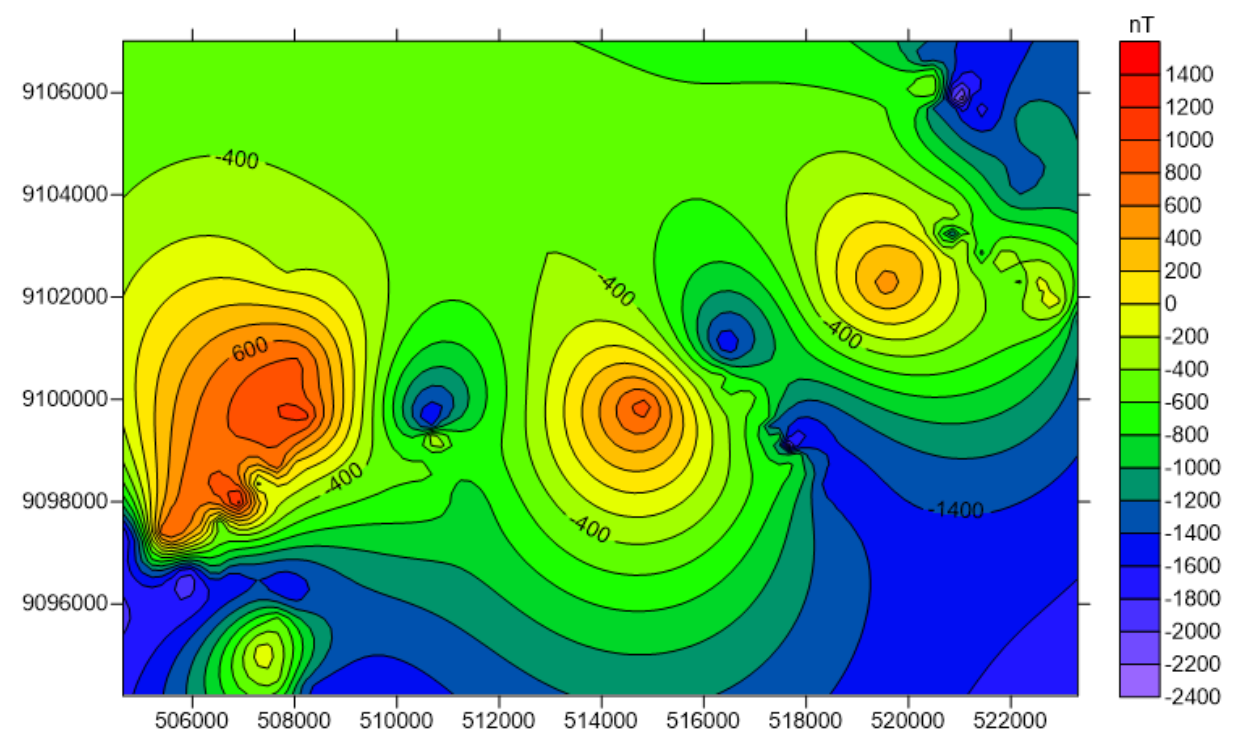

Figure 4. Contour for the Magnetic Anomaly in the Study Area Calculated Using Equation 2

As indicated, a filtering technique of upward continuation was then performed to acquire both the local and regional anomalies separately. This technique was applied to set a local altitude of observations to a point of which all noises of short-wavelengths were minimized by continuing the potential field upward $[1,25]$. This technique filtered out the effects of near-surface heterogeneities, as these are not of primary interest here [29]. While minimizing all undesirable sources of relatively shorter wavelengths, this technique makes the final results easy to interpret [32].

In the present study, this technique was performed in consecutive steps, starting from a height of $100 \mathrm{~m}$ reaching to a height of up to $900 \mathrm{~m}$ where anomaly contour was finally unaltered. The corresponding final results for the separate local and regional anomalies are provided in separate plots shown in Figure 5 and Figure 6, respectively. A clear difference in the closure size between the two figures is attributable to a distinct pattern of apparently small closures depicted in Figure 5 relatively compared to the larger ones seen in Figure 6. Regarding this difference, it follows that the resulting upward-continued anomaly signals provide information more about sources of relatively long-wavelengths at greater depths since the local, near-surface sources tend to be diminished by the upward continuation transformation process $[1,25,29,32]$. Hence, the separate anomalies allow us to focus on which anomaly that can be possibly used to possibly locate the Grindulu fault. However, the apparent anomalies remain unclear due to arbitrarily magnetized sources in view of the direction of geomagnetic field at the sites. 


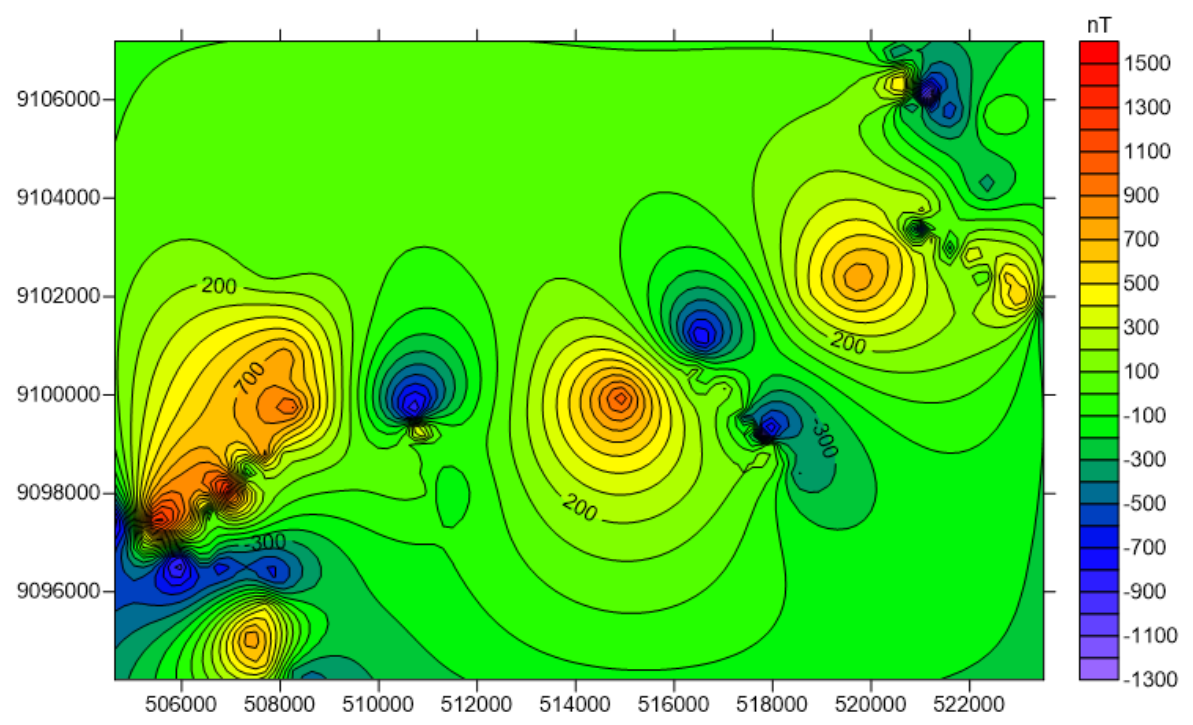

Figure 5. Contour for the Local Anomaly Resulted from Upward Continuation at a Height of $900 \mathbf{m}$

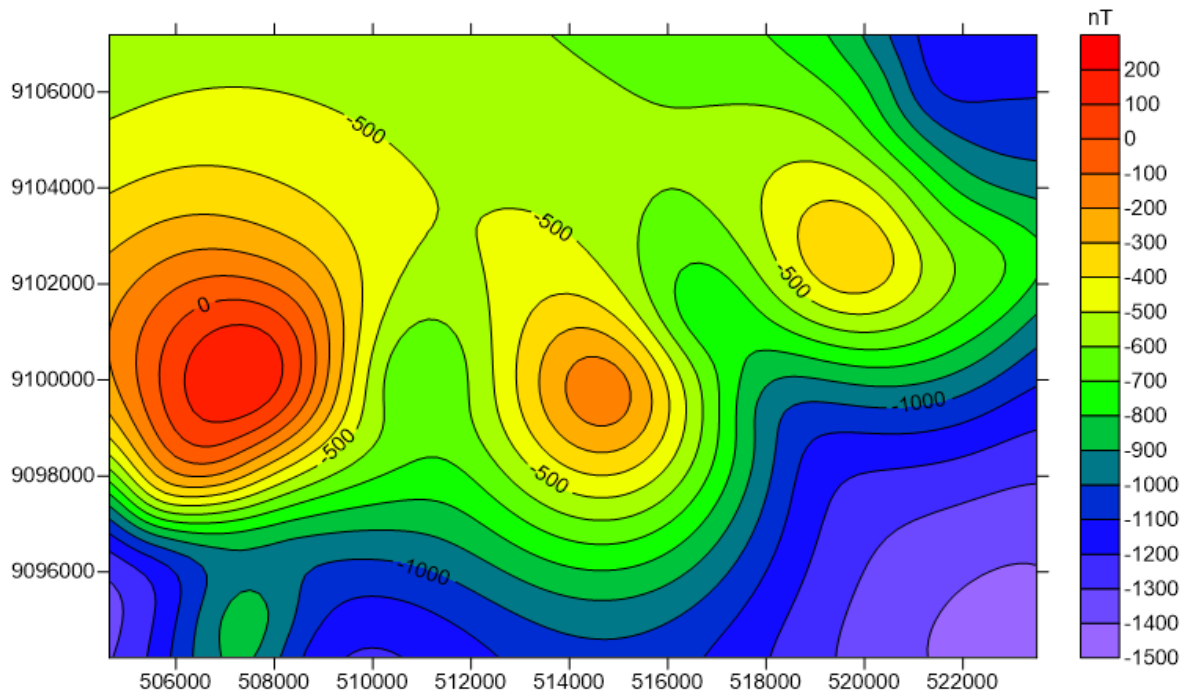

Figure 6. Contour for the Regional Anomaly Resulted from Upward Continuation at a Height of $900 \mathrm{~m}$

Therefore, for reasons previously stated, a further filtering process namely reduction to the pole (RTP) was performed for each upward-continued anomaly contour depicted in Figure 5 and Figure 6. This process relies on the fact that the large-scale geomagnetic field is specified by the total field intensity, a dip angle above or below a horizontal plane, termed magnetic inclination and the direction with respect to the geographic north, called magnetic declination $[1,20]$, or in general by the so-called magnetic coordinates [33].

As part of enhanced data processing, the RTP filtering technique is mainly aimed at enhanced filtering hence removing the distorting effects due to both the inclination and declination directivities of the main field [34]. This altered the existing observed anomalies into the ones that would have been measured if source magnetization and the ambient field were then both vertically aligned [1,26,29]. In practice, this could be achieved by forcing the inclination to be $90^{\circ}$ and the declination to be $0^{\circ}$ at the sites of the field measurements. The resulting plots of the reduced local and regional anomalies aligning to the pole using this transformation are depicted in Figure 7 for the RTP-transformed local anomaly and in Figure 8 for the RTP-transformed regional anomaly. 


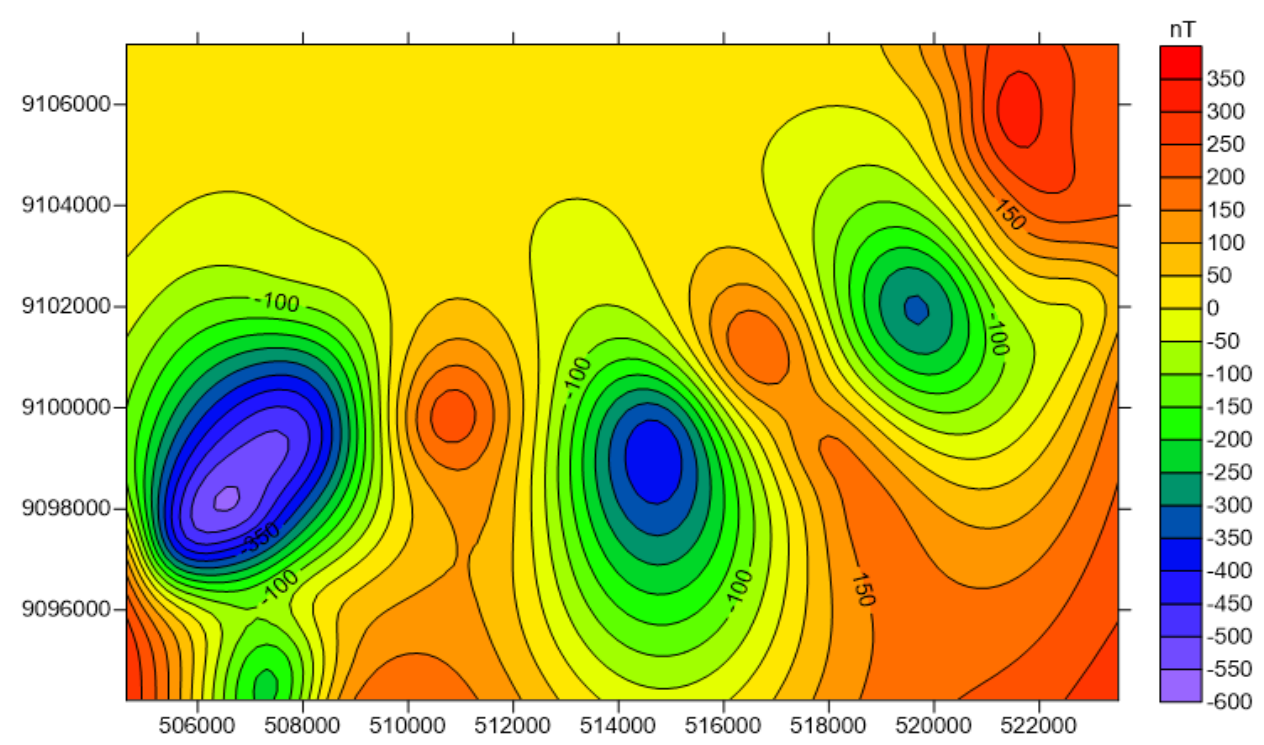

Figure 7. Contour for the RTP-Transformed Local Anomaly in the Covered Study Area

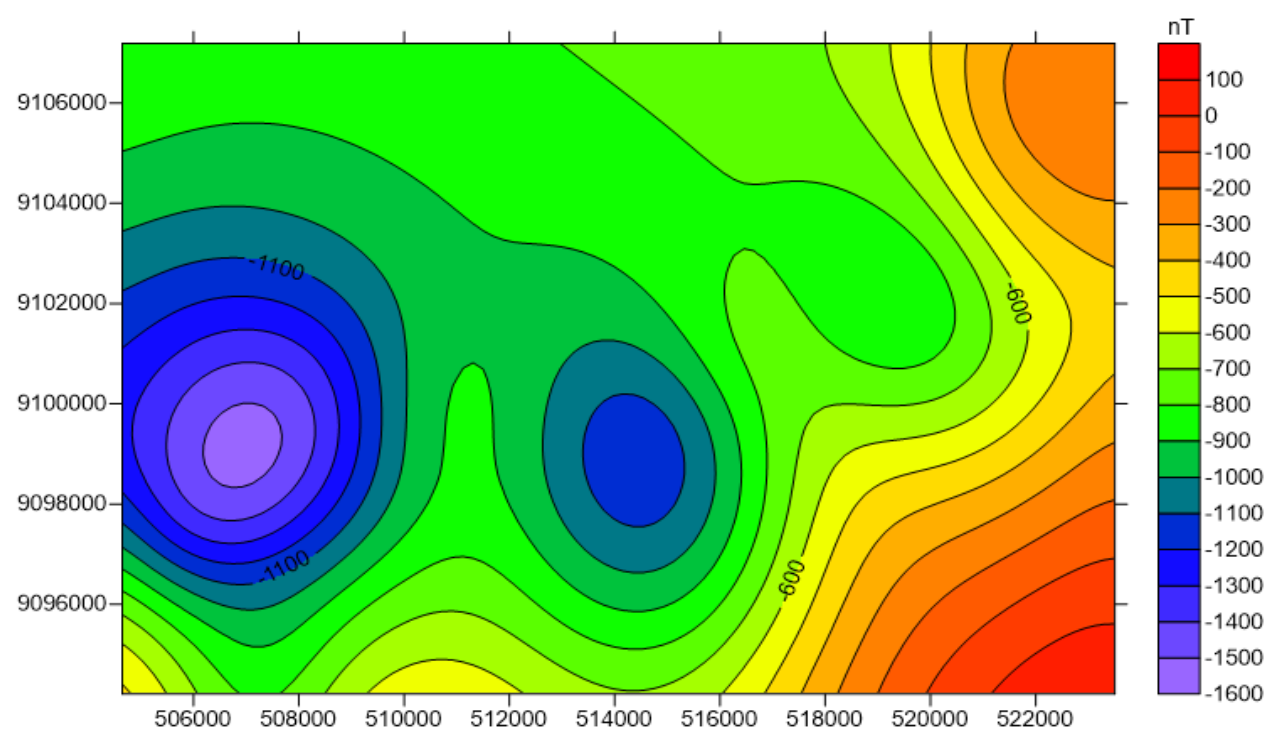

Figure 8. Contour for the RTP-Transformed Regional Anomaly in the Covered Study Area

Figure 7 shows pairs of both low-lying and high-lying closures having negative and positive anomalies, respectively. This reflects some magnetic dipoles as shallow sources with relatively short wavelengths. We argue that among magnetic noises near the surface, minor faults are potentially present at some depth neighboring the Grindulu faulting zone in Pacitan and its nearby regions, in good agreement with the finding reported by [11]. The presence of these secondary minor faults may provide insight into historical tectonics in the city and to some extent active crustal deformation in the southern area of East Java, in oppose to previous work [8,9], suggesting active shallow lithospheric motion particularly in the northern part of the province owing to back-arc thrusting.

An important feature seen in Figure 8 includes the relative dominance of closures with negative anomalies between $-100 \mathrm{nT}$ and -1600 nT over the ones with positive anomalies varying from zero to only $100 \mathrm{nT}$. As magnetic features generated by geological structures are associated with different types of rocks, the dominant negative anomalies suggest the presence of areas predominantly characterized by a depressed block of rocks 
below the surveyed area. This type of rocks is formally called graben, found in a normal fault [35] in which a layered block of rocks is partially displaced downward.

Another important feature is that there is an ambiguity induced by closures having negative anomalies; one, colored violet, is centered at approximately 507000 easting and 9099000 northing and the other, colored dark blue, at approximately 514500 easting and 9099000 northing. Using the former and in conjunction with a high-lying closure with positive anomaly at the top-right corner, we speculate that the position of the Grindulu main path in the study area is aligned along the NE-SW direction at approximately $30^{\circ}$ with respect to the east or written as $\mathrm{N} 60^{\circ} \mathrm{E}$. The dark blue closure goes with a high-lying closure at the bottom-right corner, arguably producing a secondary fault line that crosses the main path of the Grindulu making it to be a complex fault system, as indicated by [21].

It should also be noticed here that the ambiguity imposed by magnetic polarities in Figure 8 remains unresolved owing to the limitation of the RTP filtering technique [36]. This may then be reduced by transformation of a pseudo-gravity filtering technique. This transformation changed magnetic anomalies into the ones - gravity anomalies that would be observed if the source distribution of magnetization were then to be alternatively replaced with identical density distribution. A pseudo-gravity transformation might thus be useful for data analysis and interpretation as gravity anomalies are relatively easier to interpret $[1,20]$ but this is out of the scope of the present study.

In the context of seismic hazards and mitigation studies for building resilience of both local community and nation-wide issues, the main finding of the current work is then expected to increase awareness of potential seismic risks in Pacitan and its surroundings. While $[8,9]$ only prompted the northern parts of East Java that are prone to such disasters, $[11,12]$ suggested that the southern regions, such as Pacitan is also vulnerable to danger. Vulnerabilities in these regions include two other cities, Blitar [37] and Ponorogo [38], in the southern areas of the East Java province, observed using studies other than magnetic method. Therefore, this research finding significantly contributes not only to the development of geoscience in the Pacitan city and its nearby but also to the need for filling 'the gap' left by uncompleted previous work [8-10] that prompted only in the province northern areas.

\section{IV.CONCLUSION}

Magnetic method has been successfully used to delineate the Grindulu faulting zone, a geological sub-surface structure beneath the Pacitan city in the southern part of East Java, which is potentially vulnerable to seismic hazards. After data processing and associated analysis, the plot of regional anomaly contour is best used to show the main path of the Grindulu, being aligned along the NE-SW direction at about $\mathrm{N} 60^{\circ} \mathrm{E}$. The Grindulu is a normal fault featured by minor faults coming across or parallel with it, increasing the complexity to the tectonic setting in the region of interest. The results are limited with caution regarding study area coverage. Further work may apply pseudo-gravity technique and 2D modeling for removal of ambiguity in the anomalies as well as use of a wider study area to facilitate more field data that may help to identify and characterize the Grindulu accurately.

\section{ACKNOWLEDGMENT}

The authors would like to sincerely thank Lembaga Penelitian dan Pengabdian Masyarakat, Institut Teknologi Sepuluh Nopember (ITS) Surabaya, Indonesia for providing partial research fund available for this work to be completed under Hibah 
Penelitian Laboratorium Dana Lokal ITS TA 2019 by SP3 No.1060/PKS/ITS/2019. Great thanks also to Geophysics Laboratory crews, Physics Department, ITS for the help during field preparation.

\section{REFERENCES}

[1] Blakely RJ. Potential Theory in Gravity and Magnetic Applications. Cambridge: Cambridge University Press; 1995.

[2] Anchuela OP, Lafuente P, Arlegui L, Liesa CL, and Simón JL. Geophysical Characterization of Buried Active Faults: The Concud Fault (Iberian Chain, NE Spain). International Journal of Earth Sciences. 2016; 105: 2221-2239. DOI: https://doi.org/10.1007/s00531-015-1283-y.

[3] Syukri M, Marwan, Safitri R, Fadli Z, Andika F, and Saad R. Ground Magnetic Survey Used to Identify The Weathered Zone, in Blang Bintang, Aceh, Indonesia. IOP Conference Series: Earth and Environmental Science. 2017; 56: 012017. DOI: https://dx.doi.org/10.1088/1755-1315/56/1/0 12017.

[4] Saheel AS, Bin Samsudin AR, and Bin Hamzah U. Mapping of Faults in The Libyan Sirte Basin by Magnetic Surveys. Sains Malaysiana. 2011; 40(8): 853-864. Available from:

http://www.ukm.my/jsm/pdf_files/SM-PDF40-8-2011/06\%20Umar.pdf.

[5] Araffa SAS, Santos FAM, and Arefa-Hamid T. Delineating Active Faults by Using Integrated Geophysical Data at Northeastern Part of Cairo, Egypt. NRIAG Journal of Astronomy and Geophysics. 2012; 1(1): 33-44. DOI:

https://doi.org/10.1016/j.nrjag.2012.11.004.

[6] Pereira AND. Geophysical Fault Mapping Using The Magnetic Method at Hickory Sandstone Aquifer, Ilano Uplift, Texas. Dissertation. Unpublished. Texas: Texas A \& M University; 2013.
[7] Supendi P, Nugraha AD, Puspito NT, Widiyantoro S, and Daryono D.. Identification of Active Faults in West Java, Indonesia, Based on Earthquake Hypocenter Determination, Relocation, and Focal Mechanism Analysis. Geoscience Letters. 2018; 5: 31. DOI: https://doi.org/10.1186/s40562-018-0130-y.

[8] Koulali A, Susilo S, McClusky S, Meilano I, Cummins P, Tregoning P, Lister G, Efendi J, and Syafi'I MA. Crustal Strain Partitioning and The Associated Earthquake Hazard In The Eastern Sunda-Banda Arc. Geophysical Research Letters. 2016; 43(5): 1943-1949. DOI:

http://dx.doi.org/10.1002/2016GL067941.

[9] Pusat Sudi Gempa Nasional. Peta Sumber dan Bahaya Gempa Indonesia Tahun 2017. Bandung: Pusat Litbang Perumahan dan Permukiman, Kementerian Pekerjaan Umum dan Perumahan Rakyat; 2017.

[10] Cummins PR. Geohazards in Indonesia: Earth Science for Disaster Risk Reduction Introduction. Geological Society of London: Special Publications. 2017; 441(1): 1-7. DOI: https://doi.org/10.1144/SP441.11.

[11] Sungkono dan Santosa BJ. Laporan Akhir Program Penelitian Laboratorium Dana Lokal ITS Tahun Anggaran 2019. Research Report. Unpublished. Surabaya: Institut Teknologi Sepuluh Nopember; 2019.

[12] Susilo A and Adnan Z. Probabilistic Seismic Hazard Analysis of East Java region, Indonesia. International Journal of Computer and Electrical Engineering. 2013; 5(3): 341-344. DOI:

https://doi.org/10.7763/IJCEE.2013.V5.728

[13] Smyth HR, Hall R, and Nicholls GJ. Cenozoic Volcanic Arc History of East Java, Indonesia: The Stratigraphic Record of Eruptions on an Active Continental Margin. The Geological Society of America Special Paper. 2008; 436: 199-222. DOI: https://doi.org/10.1130/2008.2436(10). 
Jurnal Penelitian Fisika dan Aplikasinya (JPFA), 2020; 10(1): 22-33

[14] Hall R. Late Jurassic Cenozoic Reconstruction of the Indonesian Region and the Indian Ocean. Tectonophysics. 2012; 570-571: 1-41. DOI: https://doi.org/10.1016/j.tecto.2012.04.021.

[15] Lei Y, Jiao L, and Chen H. Possible Correlation Between The Vertical Component of Lithospheric Magnetic Field and Continental Seismicity. Earth, Planets and Space. 2018: 70(179); 1-19. DOI: https://doi.org/10.1186/s40623-018-0949-7.

[16] Araffa SAS, El-Bohoty M, Heleika AM, Mekkawi $\mathrm{M}$, Ismail $\mathrm{E}$, Khalil $\mathrm{A}$, and El-Razek EMA. Implementation Of Magnetic and Gravity Methods to Delineate The Subsurface Structural Features of The Basement Complex in Central Sinai Area, Egypt. NRIAG Journal of Astronomy and Geophysics. 2018; 7(1): 162-174. DOI: https://doi.org/10.1016/j.nrjag.2017.12.002.

[17] Panovska S, Korte M, and Constable CG. One Hundred Thousand Years of Geomagnetic Evolution. Review of Geophysics. 2019; 57(4): 1-49. DOI: http://doi.org/10.1029/2019RG000656.

[18] Wicht J and Sanchez S. Advances in Geodynamo Modeling. Geophysical and Astrophysical Fluid Dynamics. 2019; 113(1-2): 2-50. DOI:

https://doi.org/10.1080/03091929.2019.159 7074.

[19] Bukhari SY. Magnetic Susceptibilities and Fault Surface Anomalies. The Study of Land Magnetic Data \& Interpretations. International Journal of Recent Technology and Engineering. 2019; 7(6): 1053-1056. Available from:

https://www.ijrte.org/wp-content/uploads/pa pers/v7i6/F2654037619.pdf.

[20] Hinze WJ, Von Frese RRB, and Saad AH. Gravity and Magnetic Explorations: principles, practices, and applications. Cambridge: Cambridge University Press; 2013.
[21] Samodra H, Gafoer S, dan Tjokrosapoetro S. Peta Geologi Lembar Pacitan, Jawa. Pusat Penelitian dan Pengembangan Geologi. 1992. Available from:

https://opac.perpusnas.go.id/DetailOpac.asp $\mathrm{x}$ ?id=369362.

[22] Al-Hakim AY and Sulistijo B. Integrated Exploration Method to Determine $\mathrm{Cu}$ Prospect in Seweden District, Blitar, East Java. Procedia Earth and Planetary Science. 2013; 6: 64-69. Available from:

https://core.ac.uk/download/pdf/82350337.p df.

[23] Alken P, Maus S, Chulliat A, Manoj C. NOAA/NGDC Candidate Models for the 12th Generation International Geomagnetic Reference Field. Earth, Planets and Space. 2015; 67(68): 1-9. DOI:

https://doi.org/10.1186/s40623-015-0215-1.

[24] Thébault E, Finlay CC, Beggan CD, Alken P, Aubert J, Barrois O, Bertrand F, Bondar T, Boness A, Brocco L, Canet E, Chambodut A, Chulliat A, Coïsson P, Civet F, Du1 A, Fournier A, Fratter I, Gillet N, Hamilton B, Hamoudi M, Hulot G, Jager T, Korte M, Kuang W, Lalanne X, Langlais B, Léger JM, Lesur V, Lowes FJ, Macmillan S, Mandea M, Manoj Ch, Maus S, Olsen N, Petrov V, Ridley V, Rother M, Sabaka TJ, Saturnino D, Schachtschneider R, Siro O, Tangborn A, Thomson A, Tøffner-Clausen L, Vigneron $P$, Wardinski I, and Zvereva T. International Geomagnetic Reference Field: the 12th Generation. Earth, Planets, and Space. 2015: 67(79); 1-19. DOI:

https://doi.org/10.1186/s40623-015-0228-9.

[25] Ravat D. Upward and Downward Continuation. In: Gubbins D, and Herrero-Bervera E (Eds). Encyclopedia of Geomagnetism and Paleomagnetism. Switzerland: Springer; 2007: 974-976. DOI: https://doi.org/10.1007/978-1-4020-4423-6_ $\underline{311}$. 
[26] Ravat D. Reduction to Pole. In: Gubbins D, and Herrero-Bervera E (Eds). Encyclopedia of Geomagnetism and Paleomagnetism. Switzerland: Springer; 2007: 856-857. DOI: https://dx.doi.org/10.1007/978-1-4020-4423 $\underline{-6 \_275}$.

[27] Oehler JF, Rouxel D, and Lequentrec-Lalancette MF. Comparison of Global Geomagnetic Field Models and Evaluation Using Marine Datasets in The North-Eastern Atlantic Ocean and Western Mediterranean Sea. Earth, Planets, and Space. 2018; 70(99): 1-15. DOI: https://doi.org/10.1186/s40623-018-0872-y.

[28] Yamazaki Y and Maute A. Sq and EEJ-A Review on The Daily Variation of The Geomagnetic Field Caused by Ionospheric Dynamo Currents. Space Science Reviews. 2017; 206: 299-405. DOI: https://doi.org/10.1007/s11214-016-0282-z.

[29] Everett ME. Near-Surface Applied Geophysics. Cambridge: Cambridge University Press; 2013. DOI: https://doi.org/10.1017/CBO978113908843 $\underline{5}$.

[30] Borovsky JE and Shprits YY. Is the Dst Index Sufficient to Define All Geospace Storms? Journal of Geophysical Research: Space Physics. 2018; 122(11): 11543-11547. DOI: https://doi.org/10.1002/2017JA024679.

[31] Pilkington $\mathrm{M}$ and Boulanger O. Potential Field Continuation Between Arbitrary Surfaces - Comparing Methods. Geophysics. 2017; 82(3): 9-25. DOI: https://doi.org/10.1190/GEO2016-0210.1.

[32] Ilapadila, Harimei B, and Maria. Analysis of Regional Anomaly on Magnetic Data Using the Upward Continuation Method. IOP Conference Series: Earth and Environmental Science. 2019; 279: 012037. DOI:

https://dx.doi.org/10.1088/1755-1315/279/1/ $\underline{012037}$.
[33] Laundal KM and Richmond AD. Magnetic Coordinate Systems. Space Science Reviews. 2017; 206: 27-59. DOI:

https://doi.org/10.1007/s11214-016-0275-y.

[34] Amoah BK, Dadzie I, and Takyi-Keremeh K. Integrating Gravity and Magnetic Field Data to Delineate Structurally Controlled Gold Mineralization in the Sefwi Belt of Ghana. Journal of Geophysics and Engineering. 2018; 15(4): 1197-12303. DOI: https://doi.org/10.1088/1742-2140/aaa7b2.

[35] Karasozën E, Nissen E, Bergman EA, Johnson KL, and Walters EJ. Normal Faulting in The Simav Graben of Western Turkey Reassessed with Calibrated Earthquake Relocations. Journal of Geophysical Research: Solid Earth. 2016; 121(6): 4553-4574. DOI: https://doi.org/10.1002/2016JB012828.

[36] Ibraheem IM, Haggag $M$ and Tezkan B. Edge Detectors as Structural Imaging Tools Using Aeromagnetic Data: A Case Study of Sohag Area, Egypt. Geosciences. 2019; 9(5): 1-13. DOI:

https://doi.org/10.3390/geosciences9050211.

[37] Susilo A, Sunaryo, Fitriah F, and Sarjiyana. Fault Analysis in Pohgajih Village, Blitar, Indonesia Using Resistivity Method for Hazard Risk Reduction. International Journal of GEOMATE. 2018; 14(41): 111-118. DOI: https://doi.org/10.21660/2018.41.87552.

[38] Nisa' AK, Irawan MI, and Pratomo DG. Identification of Potential Landslide Disaster in East Java Using Neural Network Model (Case Study: District of Ponogoro). Journal of Physics: Conference Series. 2019; 1366: 012095. DOI:

https://dx.doi.org/10.1088/1742-6596/1366/ $\underline{1 / 012095}$. 